"Genetics and the Origin of the Species" and "Biological Lexicon". His published papers deal largely with problems of experimental embryology and embryological genetics.

\section{The Canadian Defence Research Board}

Mr. E. Lr. DavIES, vice-chairman of the Canadian Defence Research Board, has resigned and has been succeeded by Mr. A. H. Zimmerman, a prominent Canadian engineer. Dr. G. S. Field, formerly scientific adviser to the Chief of the Naval Staff, has been appointed chief scientist. Dr. N. W. Morton, chief of the Division involving operational and medical research, human resources and environmental protection, and Dr. John W. Abrams, superintendent of the Board's Operational Research Group, have been appointed scientific advisers to the Chief of the General Staff and the Chief of the Air Staff, respectively. Dr. F. H. Sanders is to become scientific adviser to the Chief of the Naval Staff. Mr. G. M. Carrie, whose Division is concerned with special weapons and northern activities, and Dr. J. J. Green, chief of the Division which directs activities in the fields of armaments and aeronautics, will combine with their present duties the task of increasing and reorganizing the headquarters' scientific staff. Dr. William Petrie has been appointed acting superintendent of the Operational Research Group.

\section{Shipbuilding Research in Britain}

A meeting of the Parliamentary and Scientific Committee on December 7 was addressed by Mr. Charles Connell, chairman of the British Shipbuilding Research Association, and by Dr. S. Livingston Smith, the director of research, on recent developments in research and technology in the British shipbuilding industry. Mr. Connell, who limited himself chiefly to questions of policy, pointed out that British shipbuilding has a long history of technical progress and cannot be accused of backwardness in applying scientific ideas. It should be remembered, moreover, that a ship and its machinery represent a capital investment of the order of $£ 1$ million with a working life of more than twenty years. Mr. Connell, however, is concerned about the question of publication of research results, and urged that results likely to benefit industry should only be communicated to British industry in the first instance. In shipbuilding research, the policy is to send all research results first to member firms in confidence, and later the commercial advantage of each report is assessed on its merits before a decision about publication is taken. Mr. Connell also pleaded for further financial support from the Government for the Research Association, in view of foreign competition.

Dr. Livingston Smith, in his paper, gave some details of the work of the Association, much of which is undertaken extra-murally and on board ship. The Association has shown that reductions of up to five per cent in frictional resistance of a ship's hull can be obtained by a better finish on the painted surface, and tests at Glengarnock on full-scale components of ships' structures have led to improvements in construction and large savings of steel. A comprehensive series of tests of propulsion and resistance carried out in ship-model testing tanks on a range of models of ocean-going merchant ship forms have yielded data of great value to designers; and investigations on noise have led to the adoption of less expensive methods than that of acoustic lining in the engine room and elsewhere. Investigations into the causes of crankcase explosions and their prevention promise to reduce considerably this hazard.

Nuffield Foundation :

Ten Years Grants

ThE Nuffield Foundation has now published the second part of its review of its first ten years (pp. 319. The Foundation, London, 1954), which was promised when the review of the main policies pursued and the kinds of work supported was issued in 1953 (see Nature, 171,851 ; 1953). In doing so, however, that admirable first part has been incorporated in the appropriate sections of this report, so that this new volume gives a more detailed record of the grants themselves and the progress made, to which are appended complete lists of Nuffield Foundation Fellows, Scholars, Bursars, etc., appointed during the first ten years and published research attributed, in whole or in part, to the Foundation's grants and awards ; in this way it provides a clear guide to the policies pursued and the principles determining grants. The first part is thus entirely superseded by the second save only where it may be a convenience to have the general account run consecutively and unbroken by detail. Be that as it may, this report on grants made during the ten years April 1943March 1953 will stand on its own as an authoritative and well-arranged reference work on the Foundation's activities during that decade. There is an adequate index. This admirably written account of the way in which the private and independent institution can still function in the Welfare State provides a most impressive vindication of the principle of voluntary action.

Fellowships, Scholarships and Bursaries

THE Nuffield Foundation is offering a number of scholarships and bursaries for postgraduate training in biology and sociology. Those in biology are intended for graduates in physics, chemistry, mathematics or engineering; those in sociology for graduates in the natural sciences and the humanities. Applicants should be 22-35 years of age and normally resident in the United Kingdom. The scholarship is valued at $£ 500-600$ a year (plus fees), with certain allowances for married holders ; a bursary is valued at $£ 350$ a year (plus fees), also with certain allowances. Applications for the biological awards must be made by April 1; those for the sociological by May 1. The Foundation is also offering fellowships and scholarships in dentistry in order to enable holders with dental qualifications to receive such additional training in pure and applied science as is desirable to fit them for an academic career in dentistry or to assist university graduates in medicine or science in receiving training which will qualify them to undertake teaching and fundamental research in dental health and disease. A fellowship is valued at $£ 500$ 800, with travelling expenses; a scholarship covers tuition fees and a subsistence allowance of up to $£ 200$ a year. Applications for fellowships must be made by March 1; those for scholarships by June 30 . Further information can be obtained from the Director, Nuffield Foundation, Nuffield Lodge, Regent's Park, London, N.W.I.

\section{Statistical Methods in Industry}

THE International Statistical Institute has just begun publication of the International Journal of Abstracts on Statistical Methods in Industry (annual subscription 2.50 dollars (18s, or 9.50 guilders), from the Institute, at 2 Oostduinlaan, The Hague, Nether. 